\title{
ЂОКИЦА Р. ЈОВАНОВИЋ ${ }^{1}$
}

\section{О ЖРТВОВАҢУ И САМООДРЖАЮУ}

\section{Јеgно ӣумачење}

САЖЕТАК. Једно од полазних места јесте мисао Бранка Лазаревића, скоро заборављеног књижевног теоретичара и критичара, о томе да је жртва „једино и чисто самоодрицање”, као и од Лазаревићеве мисли о томе да смо сведоци две врсте жртве: „Носити крста за жртву значи да је личност још 'са ове стране'. Жртвовати се значи да је личност ушла у 'ону страну”. Аутор се у овом тексту бави феноменом тзв. транспарентне, видљиве жртве, дакле оне жртве која се налази „са ове стране”, која је као таква, једина видљива социолошком разматрању. Основна претпоставка је да се у темељу културе жртвовања налази потреба за са-учествовањем, за субмисивношћу у односу према ауторитету (војном, религијском, политичком...) као услову са-опстанка у једној заједници. Опстанак је могућ као продужетак физичке егзистенције или као партиципативни део комеморативне културе. Разматра се претпоставка да се култура жртве, између осталог, конституише и под претњом казне (од физичке до моралне). У раду се разматрају налази и ставови руских аутора о томе да институција жртве настаје у страху од ритуалног убиства поданика, смерда, пред мртвим вождом. Наравно, не ис-

djole@ni.ac.rs

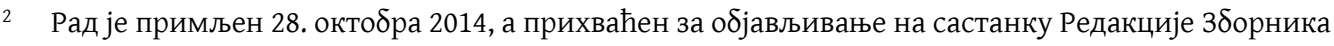
одржаном 25. децембра 2014.

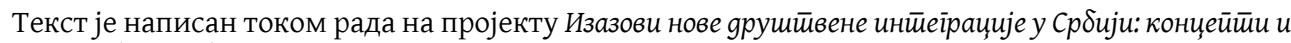
акӣери (179035), који се реализује на Филозофском факултету у Београду. Пројекат финансира Министарство просвете и науке Републике Србије. 
кључује се пракса ритуалног убијања поданика у другим и старијим културама него што је култура Прасловена.

КљУчНЕ РЕЧИ: Жртва, смерди, ауторитарна култура, сећање.

О појму жртве у социолошкој литератури нећемо наћи ни дефиниције, нити одређења којима се претендује на ексклузивну тачност. Често се, с друге стране, у исказима, текстовима и написима идеолошког или, тек, политичког карактера, овај термин немилице користи. Тако да осим, мање-више, пежоративног, идеолошко-пропагандног одређивања појма жртва немамо при руци социолошко објашњење. Са друге стране, наравно, у књижевности и есејистици реч жртва има значајно место.

Једно од тумачења полази од латинске речи sacrificium - жртва, жртвовање, а отуда sacrificatio - жртвовање. Из овога следи појам sacrificulus - свештеник (који обавља обред жртвовања). Коначно стижемо до појма sacrum - светиња, верска светковина, верски обред, религија, верска тајна. Насупрот овоме стоји profano - оскрнавити, обесветити. И, коначно, profanus - непосвећен (у нешто), невешт, безбожан, злокобан (сва тумачења премa Grujić, 1983).

Идући овим путем, задржаћемо се, надаље, код тумачења која је дао Емил Диркем (Émile Durkheim). У својој социологији религије он „прави разлику светог наспрам световног. За Емила Диркема и за све потоње социологе религије, прихватање разлике између ова два термина је постало основом њихове субдисциплине" (Marshall, 1998). Диркем, дакле, разликује свето од световног или сакрално од профаног. И док је оно што је профано, мање-више, јасно и разговетно видљиво као овострани, овде-исада, свет, сакрално измиче разумском поимању ствари. „Подела света на два подручја - од којих једно обухвата све што је свето а друго све што је профано - јесте дистинктивна црта религијске мисли... Но, под светим стварима не треба разумети напросто она персонална бића која се називају боговима или духовима; нека стена, стабло, извор, камичак, комад дрвета, кућа - једном речју, било која ствар - могу да буду свети... има речи, гласова и формула које могу да прозборе само посвећене личности; има кретњи или покрета које не могу сви да обављају" (Dirkem, 1982, стр. 35). То што је свето и што је карактеристично за религијско јесте натприродно. „Под тим се разуме сваки поредак ствари који превазилази домашај нашег разума: натприродно - то је свет мистерије, несазнатљивог, несхватљивог" (Dirkem, 1982, стр. 
24). Управо је „натприродно” ствар колективне мисли, дакле, људског света. „Општи закључак... гласи да је религија изразито друштвена ствар. Религијске представе су колективне представе

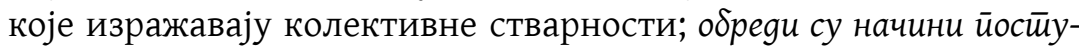
йања који се рађају само у крилу окуйљених іруйа (курзив - Ђ. Ј.)..." (Dirkem, 1982, стр. 11). Управо је овај Диркемов закључак изазвао

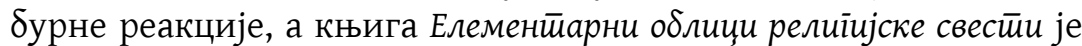
побудила велику пажњу. „’Богови су', сажеће Диркем своје опште становиште у једној бурној расправи која је уследила по објављивању Елеменйарних облика, 'само персонификовани колективни идеали" (Mimica, y: Dirkem, 1982, стр. XII). Отуда је света ствар, коју човек чини светом, недодирљива „par excellence, она коју профани човек не сме и не може некажњено дотаћи" (Dirkem, 1982, стр. 38). Али, како „интереси целине нису нужно и интереси једног њеног дела; стога се друштво не може уобличити ни одржати а да од нас не изискује непрестане жртве које нас скупо коштају. Самим тим што нас превазилази, приморава нас да сами себе надмашујемо... што не пролази без мање или више мучне напетости" (Dirkem, 2007a, стр. 159). Оно што је услов опстанка групе јесте вредност која надмашује вредност сваког појединца понаосо $\delta$ - то је морал. Као што се види, друштво од нас стално захтева жртве да би могло да опстане као морална заједница. „Морал, дакле, започиње тамо где започиње групни живот, пошто само ту пожртвованост и несебичност имају смисла. Кажем - групни живот, уопштено говорећи... Елем, морални живот започиње чим постоји везаност за групу, ма колико ова потоња била скучена" (Dirkem, 2007反, стр. 120). Жртва утолико мора да буде (морални) чин којим ће се одржати добар друштвени поредак и зато она мора да буде слободна и спонтана радња. Тачније, често заједница захтева и очекује од оних који се жртвују да то чине „слободно и спонтано”. Утолико, ни заједница, нити ауторитет не дугују ништа жртви, осим онога што су спремни да као дуг прихвате. То су „слободне и спонтане радње, жртве које ништа не изискују и које су понекад чак и супротне прописима разборите економичности. Има врлина које су праве лудости, а великим их чини управо њихова лудост" (Dirkem, 2007в, стр. 135).

Зато ће наш, значајан и заборављен, књижевни критичар Бранко Лазаревић о жртви рећи ово: „То је једна велика појава код човека. Жртва је једино и чисто самоодрицање. Личност се појављује у њој сасвим ван сваког плана. Она се више не види; види се само предмет који је замењује. Тај предмет је увек нека лич- 
ност или појава са којом се она мења” (Лазаревић, 2005, стр. 63). Три су жртве, наставља Лазаревић. „Прва је када је личност толико уништена да је боље заменити је жртвом. То је саможива жртва. Друга је врста кад је предмет који замењује личност већи од личности. То је жртва када је пожртвовање, мада тешко, ипак пријатно. Трећа је жртва највећа. То је жртва када се ништа не пита и ништа не мери. Ту се све толико жртвује да се она и не види више... Личност је потпуно ишчезла, и само се види велика појава у коју се личност претворила.” Лазаревић завршава следећим речима „Носити крст за жртву значи да је личност још 'са ове стране'. Жртвовати се значи да је личност ушла у 'ону страну"' (Лазаревић, 2005, стр. 64).

Ту и такву жртву, када, како Лазаревић каже, она нестаје, када одлази у „ону страну”, жртву „која ништа не тражи”, како каже Диркем, жели и захтева сваки ауторитет да положи на олтар сопствене „светости” - ма какав тај ауторитет био: државни или религијски. Тако се и жртвама датим за државу, религију, идеологију... приписује легитимацијски капацитет, који се уграђује у идеју државе, у религију, у идеологију... Са друге стране, они, од којих се очекује жртвовање и који се жртвују, често граде разне стратегије како да од сопствене жртве имају какво добро, па, макар и онда када дају живот. Па, чак и онда, када жртва потптуно нестаје (Лазаревић) она остаје, вероватно, за неко дуже или краће време, достојна сећања, она је део комеморабилности ${ }^{3}$. То сећање, чак и ма како танушно и кратко било, јесте сећање - оно је продужетак трајања онога ко се жртвовао. Догађа се овакав случај и у једном сасвим профаном смислу: „Особа је спремна да жртвује нека од својих добара уколико би добила више других добара" (Alchian \& Allen, 1995, стр. 5).

Но, пре приписивања сакралног, комеморабилног... карактера жртви, култура жртве настаје, дакако, у профаној сфери. Покушаћемо да објаснимо једну (између осталих) од првих функција друштвене улоге жртве тако што ћемо обратити пажњу на настанак установе жртве код прасловенских племена.

У једном кратком тексту (писан са очигледном намером да $\delta$ де основом доцнијег истраживања) Веселин Илић тумачи појам жртве код Словена (Илић, 1997, стр. 27). Истраживање обреда смрти које је учинио Веселин Илић указује на један важан извор, још једну важну димензију ауторитарности у култури. Илић у

3 Comměmŏrābǔlis: вредан помена, достојан сећања, знаменит (Žepić, 1989). 
свом тексту, између осталог, говори о обреду насилничке смрти војника (нарочито младих) уз умрлог или погинулог вожда/ књаза, који је нарочито упражњаван у Русији и то у дугом периоду пре примања хришћанства. Реч је о обреду који се називао „смерgu” или „саумирући”. „Као култно-религиозни институт смерgu се појављује у религијским представама Прасловена у епохама војне демократије и повезан је са процесима уздизања племенских вођа. А реч је о ритуалном убијању војника при сахрани вође племена... Прасловени су овај ирационални религиозни обред преузели од Скита" (Илић, 1997, стр. 27).

Борис Рибаков (Борис Александрович Рыбаков) указује на једну битну историјску чињеницу у развоју руске културе уопште. Наиме, руски пастири су вешто користили секиру у свакодневним пословима, али и у ратним походима. Узгајали су окретне и снажне коње. Велики, често пресудан, значај имала је вешта употреба секире, како у крчењу огромних шумских пространстава, тако и за опстанак у негостољубивом ठескрају руске тундре и тајге. Колико је секира била битна у животу руског пастира доказ је да су они њеном вештом употребом, од прихватања хришћанства $^{4}$ знали да од комада дрвета изрезбаре икону. Секира, коњ и, у доцнијем периоду, икона, налазе се у темељима руске културе. „Секира је одиграла средишњу улогу у учвршћивању нове цивилизације у подручју горњег тока Волге" (Bilington, 1988, стр. 47). Прасловени су користили секиру и као новац. Са секиром су сахрањивани. „Народ је секиру називао 'громом', а камење нађено близу дрвета обореног муњом било је штовано као део сечива секире које је користио бог грома" (Bilington, 1988, стр. 46).

Секира и снажни и окретни коњи су представљали велику моћ коју су племенске вође почеле да користе. То је омогућило да настане нови друштвени феномен - учвршћена је и неизмерно увећана моћ племенских вођа и њихових доглавника. Њихова моћ је увећавана, и правом да „после смрти смерда, ако овај нема мушког потомка, његово имање припадне 'књазу”' (Греков, 1952, стр. 109). Чак је и „смердов коњ” „књажев, са којим ради, од хазјајина-књаза зависни, смерд" (Греков, 1952, стр. 114). Раст моћи је био претпоставка настанку ратне, освајачке културе. Племенске вође су све чешће кретале у ратне походе. У таквим

4 Године 988. Владимир Велики Кијевски (Влаguмuр Великий, Великий князь Киевский) прихватио је хришћанство и владарским указом наложио покрштавање становништва (шире у: Bilington, 1988, стр. 17-32 и у D. Obolenski i R. Oti, (ur.) (2003), стр. 61-91). 
околностима требало је обезбедити лојалност потчињених и мобилисаних сељака. Лојалност се огледала првенствено у томе да мобилисани буду спремни да се жртвују за господара и да га чувају од погибељи. Управо зато настаје обичај ритуалног убијања подређених. У случају да вођа/ књаз погине у боју, на његовом гробу ће ритуално бити убијени њему потчињени и ритуално ће ठити сахрањени заједно са њим. Појава таквог обичаја је утицала на то да „смерды”, мобилисани за рат, буду врло много заинтересовани да њихов господар из сваког оружаног сукоба изађе жив - што је и била интенција успостављања таквог обичаја. То је учинило да у борби буду храбри и створило је жељу код њих да вођу заштите од опасности. Били су спремни на жртву - да буду рањени, заробљени...

Код Прасловена институција „смерды“ постоји од првих векова формирања протословенског јединства. „Могуће је да се и са̂м термин »смерды« појавио доцније, у скитско време, када је још увек овај феномен био широко распрострањен, када Словени позајмљују многе иранске речи“ (Рыбаков, 1981, стр. 263). Како ствари стоје, верност господару и жеља за његов дуг живот има, између осталог, корене и у овом древном словенском обичају. И страху за сопствени живот. Наравно, овакви обреди постоје и у другим културама - у древном Египту, у преколумбовској Америци... о чему постоје бројна антрополошка, историјска, културолошка, уметничка... истраживања. Јакобсен Торкилд (Jacobsen Thorkild), пишући о послушности пред ауторитетом која произилази из страха, каже да се она узима за прву јавну врлину:

„Смерд” - староруски израз у значењу сељак, земљоделац, кмет (прим. - Ђ. J.). Павел Јозеф Шафарик, код нас познат и као Павле Јосиф Шафарик (Pavel Jozef Šafárik) реч „смерд” тумачи овако: „Древно руско смерд (смердь, rusticus), мученик (servitus) треба упоредити са именом народа Мордвани, Мордванин (корен обе речи је персијско merd, тј. човек, мушкарац)" (Шафарик, 1837-1848, стр. 93). Има и оних који сматрају да реч „смерд” долази од словенске речи „смрдети” („смердеть”), као што то чини Франц Миклошич (Franz von Miklosich) (Miklošič, 1886, стр. 310). „Током Кијевске ере (од IX до XIII века), маса слободног сеоског становништва је била позната као смерди (у једнини смерд)... Филолози су истакли да је врло вероватно да је назив изведен из древног корена који значи 'човек'... До Кијевског периода, међутим, реч је коришћена само за најнижу класу слободних мушкараца и био је повезан са изразом смердети, 'заударати'. Онако како се употребљавало име смерд можда се најбоље може превести као 'ђубре'- то је показатељ веома ниског поштовања према сељаку. Тешко је замислити да ठи људи који су идентификовани од стране савременика тако непријатним именом могли ठити сматрани људима од икакве важности" (Blum, 1953, стр. 122). 
„Послушност се нужно издваја као примарна врлина. Држава која почива на послушности почива на неспорном прихватању ауторитета. Не изненађује откриће да се у Месопотамији под добрим животом « сматрао »послушан живот«. Појединац се налазио у средишту концентричних кругова којима је власт ограничавала његову слободу деловања" (Jacobsen, 1946, стр. 202).

Отуда се оваква верност претапа у обожавање и величање господара, а, у ствари, у (неизречену) бригу за сопствени живот. Када пук кличе вођи, он, у ствари, кличе себи и сопственом самоодржању. Просто, што више будем био (и практично) веран свом господару и то образлагао сопственом љубављу према њему, утолико ћу и ја дуже (и добро) живети. Са друге стране, господар ће бити наклоњен према мени, стално потхрањујући моју верност, као услов сопственог живота. А, онда, ово начело се протеже и на све институције које почивају на ауторитету.

Према мишљењу Василија Абајева (Василий Иванович Абаев) реч

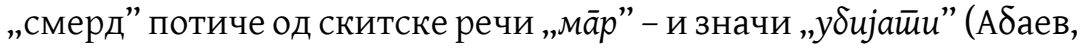
1949, стр. 172). Скити су, иначе, номадски народ и припадају племенима иранског порекла. У руском језику су се до данас за-

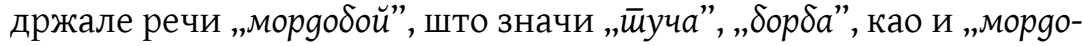

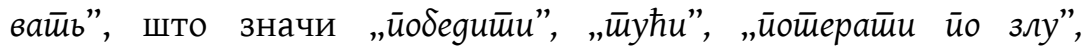

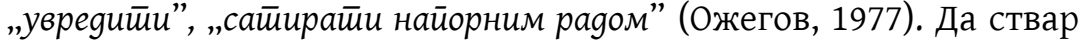
буде још јаснија, из речи „ма̄р” настаје и реч „amcedtag” (из amærddag $\rightarrow$ a-mardi-ag) што значи жмйва. (Аठаев, 1949, стр. 173). О овоме, вратимо се сад Веселину Илићу, могуће је закључивати и овако (на трагу Рибаковљевог истраживања): „руско смерgы има значење заједничкоумирући, заједно приношени на жртву... Овакву интерпретацију етимологије смеpg Б. А. Рибаков заснива на чињеници што је ова реч управо настала у временима снажног утицаја Скита на Прасловене. Тада је, према најновијим истраживањима, дошло до врло важне замене прасловенског/ индоевропског gеуса иранским боїом код Прасловена" (Илић, 1997, стр. 27).

Како Веселин Илић наводи, „та насилничка смрт младих војника уз вожда/ цара - загонетни култно-религиозни обред смер$g u, \ldots .$. примењивао се у Русији IX и Х века” (Илић, 1997, стр. 28). обичај је постојао углавном код западних Словена. Код Јужних Словена и Срба, пише даље Веселин Илић, смерgu се у историјским изворима не помињу. Међутим, он проналази код Вука Караџића, како каже, одблесак преобликоване митологеме о смер-

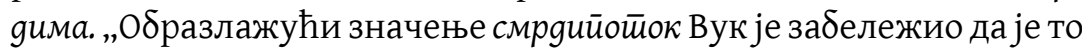
'код Голубца у нахији пожаревачкој поток, који се, као што се 
онда приповиједа, тако прозвао од многијех мртваца, који су ондје још пре Христа негда изгинули' (Караџић, 1964, стр. 218)" (Илић, 1997, стр. 28). Даље, упућује нас Веселин Илић ка једном могућем значењу код нас. „Дакако сачуван је само деформисани смисао поруке мита о саумирућима, његова рудиментарна бит о величини чина колективне смрӣи за вожда и домовину. Из дубина митолошко-симболичких значења овога ритуала може се разабрати и смисао његове опште социјалне поруке. Из овога застрашујућег погребног рийуала при сахрањивању происходе, очито, и вредности особене, али истовремено и рудиментарне патриотске свести о домовини и код савремених Срба" (Илић, 1997, стр, 28).

Самоодржање је, види се из реченог, дериват не идеје о једнакости у друштву, о којој у средњем веку није могло бити ни говоpa. Јохан Хојзинга (Johan Huizinga) пише да је „средњовјековном (je) човјеку била, наиме, битна точка те мисли у блиској једнакости у смрти, а не у некој безнадној далекој једнакости у животу" (Huizinga, 1991, стр. 56). Оठећање једнакости је, у исто време док је жртва (као жртва неједнакости) сакрализована, померено у сферу оностране награде. Зато је стратегије самоодржања правио онај ко је подређен, али и онај ко је надређен. Свако са своје класне позиције и са позиције моћи којом располаже. Ко год је имао власт, или је био претендент на власт - обећавао је награду, али је и претио казном, смрћу. Дакле, „од мртвих не живе само гробари, него и власт” (Kuljić, 2013, стр. 5). Дакле, у самом чину жртвовања и саможртвовања постоји јака димензија субмисивности. Према томе,

„жртва (према старосл. жрьтва) је приношење неке ствари (жртвеног дара) божанству, херојима, прецима, било којем наднаравном бићу или живу човјеку, да му се искаже част, призна власт, да се умилостиви. Жртвом се назива и сам жртвени дар, а жртвовање се састоји у њезину уништењу (спаљивању, конзумацији) чиме прелази из профане сфере у сакралну. Основа је жртве божански антропоморфизам; она је везана... за поштивање хероизираних предака, те коначно за институционализирани, заједнички култ племена, града, државе.... Антички народи веома су цијенили херојску, добровољну, жртву властитог живота (или нечега што је човјеку најдрагоцјеније) за домовину, за правду, истину, за свој позив или другу узвишену идеју. Неке су жртве приказане као дирљив литерарни или ликовни мотив" (Šentija, 1977-1988). 
Приношењем жртве (стварним или симболичким одузимањем живота) се, у ствари, гарантује егзистенција ауторитета. То гарантовање се испољава као обожавање, поштовање, подређивање... Отуда је „жртва чин којим се у ритуалу већине инстиийциионализираних релиіија нуди или посвећује предмету обожавања или одређују за упорабу светишта нека ствар или особа (курзив - Ђ. Ј.). Тај чин често обухваћа и уништавање понуђене ствари" (Mandić, 1977).

Како ова свечаност смрти опстаје до наших дана? Веселин Илић на другом месту даје одговор на ово питање говорећи о миту:

„....у његовој не-апсолутној истини находе се она духовно-метафизичка својства која му обезбеђују одреднице посеঠне универзалне симболичке форме културе, какве су и језик и уметност" (Илић, 1990, стр, 16).

До сличних закључака о настанку државног ауторитета, који егзистира тако што монополизује право на омогућавање, тј. онемогућавање живота својих поданика, идући другим путем, долази Карл Витфогел (Karl A. Wittfogel) у својој значајној, и код нас већ заборављеној, студији Оријенйална gесйоциија. На питање о „тоталној покорности" он каже је покорност постала ствар васпитања, при чему појединац не влада својом судбином (па ни својим животом):

„Одгој учи човјека да слуша ठез поговора кад то захтијева деспотски ауторитет. Он га учи да чини гесте страхопоштовања кад то захтијева симбол а не истински акт покоравања. Наравно, све културе посједују облике пуног поштовања, а покорност се може изразити на различите начине. Али ниједан други симбол не предочује тако увјерљиво тоталну покорност и ниједан није тако безизузетно повезан с аграрном деспоцијом као акт ठацања ничице на тло - прострација"6 (Wittfogel, 1988, стр, 168).

Услов опстанка ठило ког „наддруштвеног” ауторитета јесте поседовање ексклузивног права на монополизовање права на живот својих поданика или грађана. Она то чини, наравно, практиковањем прерогатива којима гради свој суверенитет. Реч је о легислативном монополу и монополу на моћ. Ма како била, по устројству демократска, и ма како својим законима и праксом „штитила право на живот грађана”, она ће то право, ако никако

6 Поред овог, израз „прострација” значи и „изнемоглост”, „изнуреност”, „клонулост”, , ,слабост”, „малаксалост” (према Клајн, И. и Шипка, М, 2006). 
другачије, ставити ван снаге чином ратне мобилизације. То је видљиво у случајевима од друштвеног положаја у коме су били древноруски „смерды”, па све до данас. Наравно, форме и опсег званичне заштите људских права разликују се у великој мери у односу на време у коме су живели „смерды”. Али, она димензија која је конститутивна за успоставу ауторитета непрестанце опстаје - моћ да човек влада над човеком. Та се моћ остварује од претње до практиковања монопола на силу ${ }^{7}$, па до успостављања монолитног фетишизма робе. ${ }^{8}$ И у једном и у другом смислу се (принцип силе или фетишизам робе) подразумева и захтева жртва подређених. Са друге стране, ту моћ да одлучује о животу својих поданика и грађана, држава, а и само друштво, практиковати ће као комеморисање оних који су пристали на жртву. Пристанак на жртву се тумачи као аутономна одлука „слободних” појединаца и група људи, а зарад добра државе и заједнице. Тај чин, на тај начин, постаје конститутивно место у идеологији и

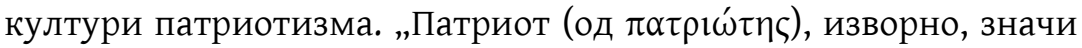

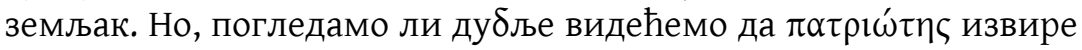

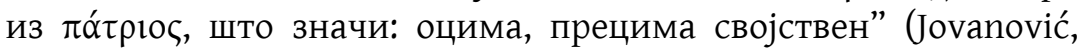
2012, стр. 211). Патриотизам, стога, представља имагинарну везу са прецима, те и са тадашњом културом (дакле, и тадашњим вредностима). Патриотизам се, с друге стране, повезује у нераскидивом смислу са жртвом. Та негдашња култура се данас, свакако, не може упражњавати, није ни жива, али јој се у оквиру комеморативне културе поклања поштовање. Чином поштовања, она се протеже до данас, и у симболичком смислу (ако не другачије) она се и сада упражњава. Према томе, с једне стране постоји сећање, прекривено особитим поштовањем (културом сећања), а с друге стране, то сећање монополизује држава или какав други политички, идеолошки или верски ауторитет, тако да у оквиру званичног државног ритуала патриотска осећања стави у службу „државног разлога”. Монополизовањем и присвајањем „патриотских осећања" држава или какав други ауторитет захтева од

7 „Шта је, дакле, држава у социолошком смислу? Држава је по свом постанку сасвим, а по својој суштини у првим периодима свог постојања готово сасвим, друштвена установа, коју је победничка људска гомила наметнула побеђеној људској гомили с једином сврхом да успостави власт над њом и да се осигура против унутрашње побуне као и против спољашњих насртаја.

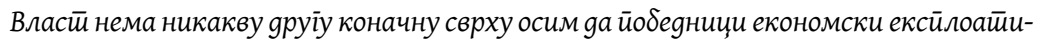
шу ӣобеђене (курзив - Ђ. Ј.)" (Орpenheimer, 1926, стр. 15).

8 „Због тога је загонетка новчаног фетиша само загонетка робног фетиша која је постала видљива и засењује очи" (Marks, 1978, стр. 92). 
потчињених спремност на жртву. Заузврат, држава сакрализује њихову спремност или „спремност” на жртву. Жртва добија комеморабилне атрибуте. Патриотизам почива на жртви. Без жртве и спремности на њу он се гаси. У том смислу појединац се подвргава ауторитету тако што ће „друштвени поредак сматрати тајном која се налази с ону страну моћи разума, као дјело супериорног разума које захтијева његову... жртву" (Rancière, 2010, стр. 112-113). Ауторитет, сматра Жак Барзун (Jacques Martin Barzun), врло често своје доктрине „обликује према онима који су слаби и сиромашни духом. Славећи беспомоћне он умножава број жртава које су уплашене и озлојеђене пред животом" (Barzun, 2000, стр. 671). Чешће него што постоји спремност да се о жртви јавно и смислено говори, довољна је и декларативна, демагошка спремност на жртву разних демагога да би она тако постала пожељан предмет утилитарне политике.

Политика никада није престала да употребљава смрт у своју сврху. Као што се некад очекивала и захтевала жртва, она се и данас захтева и то како у негдашњем, огољеном виду, тако и у виду симболичког геста жртвовања. Политика вековима развија симболички свет везан за жртву и за смрт у име идеологизовано дивинизованог разлога. Пишући о танатосоциологији (проучавање друштвених неједнакости код умирања) и танатополитици (политичка употреба смрти) Тодор Куљић каже да је „крв (је) симбол освете, a Lex talionis (дуг у крви) је честа фигура код правдања ратова и разних револуција. Формално гледано, драматизација преко симбола смрти је динамика сваке танатополитике која у правдању насилних преуређења друштвене организације нуди страдалима као накнаду разне верзије спасења" (Kuljić, 2013, стр. 14). ${ }^{9}$

И, овде се може рећи да је претпоставка спасења (као продужетка трајања) једнако моћан фактор у обликовању животних стратегија, као што је била моћна негдашња потреба за чувањем господара коју су исказивали „смерды” да би тако били спасени у чину са-постојања са господаром. У овом случају се идеолошко може тумачити и као оправдање жртвовања, с једне стране, и као

9 О танатологији и танатолошким истраживањима и о социлогији смрти, као релативно новој истраживачкој дисциплини квалификовано пише Клифтон Брајант (Clifton D. Bryant). „1970-те и 1980-те су ठиле врло продуктивне године за танатологију у истраживачком и научном смислу, те тај замах наставља да расте у новом миленијуму. Као део танатологије, социологија смрти је у снажном порасту" (Bryant, 2007, стр. 160). 
образлагање неупитности ауторитета - зарад кога и у чије име се подноси жртва, с друге стране.

ЛИТЕРАТУРА А Абаев, В. И. (1949). Осетинский язык и фольклор, I, Москва - Ленинград: Академия наук СССР.

Alchian, A. \& Allen, W. R. (1983). Exchange and Production: Competition, Coordination \& Control, Belmont: Wadsworth.

Barzun, J. (2000). From Dawn to Decadence: 500 Years of Western Cultural Life 1500 to the Present. New York: Harper Collins Publishers.

Bilington, Dž. (1988). Ikona i sekira. Istorija ruske kulture, jedno tumačenje. Beograd: Izdavačka radna organizacija „Rad”.

Blum, J. (1953). „,The Smerd in Kievan Russia”. American Slavic and East European Review, 12 (1), 122-130.

Bryant, C. D. (2007). The Sociology of Death and Dying. Y: C. D. Bryant \& D. L. Peck (Eds), 21st Century Sociology: A Reference Handbook, volume 2. Thousand Oaks: Sage Publications.

Wittfogel, K. A. (1988). Orijentalna despocija. Zagreb: Globus.

Греков, Б. Д. (1952). Крестиьяне на Руси. С gревнейших времен gо XVII века. Книга первая. Москва: Издательство Академии наук СССР.

Grujić, B. (1983). Rečnik latinsko srpskohrvatski. Beograd: Narodna knjiga, Obod, Medicinska knjiga.

Dirkem, E. (1982). Elementarni oblici religijskog života. Beograd: Prosveta.

Dirkem, E. (2007a). „Dualizam ljudske prirode i njegovi društveni uslovi”. U: A. Mimica, A. (ur.), Emil Dirkem: Društvo je čoveku bog. Beograd: Institut za sociološka istraživanja. Filozofski fakultet.

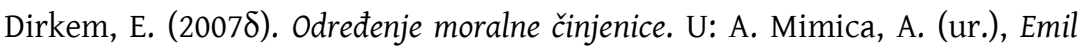
Dirkem: Društvo je čoveku bog. Beograd: Institut za sociološka istraživanja. Filozofski fakultet.

Dirkem, E. (2007B). Sudovi vrednosti i sudovi stvarnosti. U: A. Mimica, A. (ur.), Emil Dirkem: Društvo je čoveku bog. Beograd: Institut za sociološka istraživanja. Filozofski fakultet.

Иванович, О. С. (1977). Словарь русскоїо языка. Москва: Издательство „Русский язык“.

Ilić, V. (1990) Mit i stvaranje, Niš: Prosveta.

Илић, В. (1997). „О трагичности људске жртве”. У: М. Стојановић (ур.),

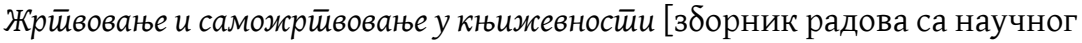
скупа одржаног у Нишкој Бањи и Алексинцу од 2. до 4. новембра 1997]. 
Jacobsen, T. (1946). „Mesopotamia”. In: H. A. Frankfort \& J. A., Wilson, T. Jacobsen, W. A., Irwin (1946), The intelectual Adventure of ancient Man: An Essay on Speculative Thought in the Ancient Near East. Chicago \& London: The University of Chicago Press.

Jovanović, Đ. (2012). Prilagođavanje. Srbija i moderna: od strepnje do sumnje. Beograd: Institut za sociološka istraživanja Filozofskog fakulteta u Beogradu, Čigoja štampa, SVEN.

Караџић, В. (1964). Расковник. Проза из Ријечника. Београд: Просвета.

Лазаревић, Б. (2005). „Сенке основа”. У: Б. Лазаревић (2005), Сабрана gела, књ. 4. Београд: Завод за уџбенике и наставна средства.

Клајн, И. и Шипка, М. (2006), Велики речник сйраних речи и израза. Нови Сад: Прометеј.

Kuljić, T. (2013). „Tanatopolitika i tanatosociologija - nacrt teorijskog i pojmovnog okvira". Sociološki diskurs, 3 (5), 5-20.

Mandić, O. (1977). Odrednica: „Žrtva”. U: M. Bosanac, O. Mandić, O. Petković (ur.), Rječnik sociologije i socijalne psihologije. Zagreb: Informator.

Marks, K. (1978). Kapital. T. 1. Beograd: Prosveta.

Marshall, G. (ed.) (1998). „Sacred, sacred versus profane distinction”. In: Dictionary of Sociology. Oxford, New York: Oxford University Press.

Miklošič, F. (1886). Etymologisches Wörterbuch der slavischen Sprachen. Wien: W. Braumüller.

Mimica, A. (1982). Sociologija religije Emila Dirkema (predgovor). U: Dirkem, E. (1982). Elementarni oblici religijskog života. Beograd: Prosveta.

Obolenski, D. i Oti, R. (ur.). (2003). Istorija Rusije. Beograd: Clio, Beograd.

Oppenheimer, F. (1926). The State. New York: Vanguard Press.

Rancière, J. (2010). Učitelj neznalica. Pet lekcija iz intelektualne emancipacije. Zagreb: Multimedijalni institut.

Рыбаков, Б. А. (1981). Язычество древних Славян. Древняя Русь: Духовная культура и государственность. Москва : Акад. проект.

Huizinga, J. (1991). Jesen srednjeg vijeka. Zagreb: Naprijed.

Шафарик, П. Й. (1837-1848). Славянские древности: Часть историческая, / Пер. с чеш. [и предисл.] О. Бодянского. - 2-е изд. Москва: изд. М. Погодиным.

Šentija, J. (gl. ur.). (1977-1988). Opća enciklopedija Jugoslavenskog leksikografskog zavoda. Zagreb: Opća enciklopedija Leksikografskog zavoda Miroslav Krleža. Dostupno na: www.4shared.com/get/107097789/22b4f43c/Enciklopedija-Opsta.html. Posećeno 1.11. 2009. 
ĐOKICA R. JOVANOVIĆ

UNIVERSITY OF BELGRADE

FACULTY OF PHILOSOPHY

One of the initial points of departure is actually an idea by Branko Lazarević, an almost forgotten writer and critic, who stated that "sacrifice and the only pure self-denial", adding that we are witness to two types of sacrifice: "Bearing a cross signifies to a victim that one still remains on the other (non-spiritual, author's note) side". Sacrificing therefore means that one has entered this (spiritual, author's note) side. In this paper the author is discussing the phenomenon of the so-called transparent, visible sacrifice, i.e. those sacrifices that are on "this side", which, as such, is the only one detectable in sociological investigations. The basic premise of the paper claims that the basis of the phenomenon of sacrifice there is a need for co-participation, submissiveness towerds authority (be it military, religious, political...) which is a condition for coexistence in a community. Survival is possible only as an extension of physical existence or as a participating part of a commemorative culture. The paper also analyses the assumption that the culture of sacrifice, among other things, constitutes itself under a set of possible punitive measures (physical or moral). Among others, some ideas by Russian authors stating that the institution of a sacrifice develops in a state of fear caused by ritual murder of a state's subjects, smerds, before the dead body of their supreme leader. The Russian writers naturally do not rule out a practice of ritual killing of subjects in different and older cultures other than that of Proto-Slavic ones.

KEYWORDS: sacrifice, smerds, authoritative culture, remembrance. 